\title{
MODELLING CENTRAL BANK INDEPENDENCE AND INFLATION: DEUS EX MACHINA?
}

\author{
Florin Dumiter PhD \\ "Vasile Goldis" Western University of Arad, Romania \\ E-mail: fdumiter@yahoo.com \\ Petre Brezeanu PhD \\ The Bucharest Academy of Economic Studies \\ E-mail: brezeanupetre@yahoo.com \\ Claudia Radu PhD \\ "Vasile Goldis" Western University of Arad, Romania \\ E-mail: raduclaudiaf@gmail.com \\ Florin Turcas PhD Candidate \\ The Bucharest Academy of Economic Studies \\ E-mail: turcasflo@gmail.com
}

(Received October 2015; accepted November 2015)

\begin{abstract}
Central bank independence represents the core element of assessing the complex relationship between government and central bank, having at background the fundamental issue of a free monetary policy decision-making process from the hands of the political circle. However, central bank independence is a multilevel concept within some social, economic and behavioral implications both for the central banks and for the society at whole. Central bank independence is needed in order to establish an autonomous central bank with a high degree of freedom in choosing its' instruments, objectives, techniques and tactics. Moreover, a high degree of transparency for the public disclosure and monitoring of central bank operation and transaction is needed for the social barometer of the central bank. Consequently the central bank must have a high degree of accountability and responsibility vis $-a ́-v i s$ of the most democratic institution, i.e. Parliament. In this article it is presented a comprehensive study regarding the complex relationship between central bank independence and inflation by modeling these two monetary policy panacea, in order to make a fine tuning regarding the causal relationship established in a heterodox manner.
\end{abstract}

Keywords: monetary policy, central bank transparency, central bank accountability, inflation performances, political influence, central bank decision-making process, bureaucratic institution.

JEL Classification: D78, E52, E58.

\section{Introduction}

In market economies, central banks were constructed in order to assure the adequate tools for covering the governments public spending. In consequence, despite the high degree of political independence that was enriched in the central bank, the economic independence level was at lower levels. The mainstream 
Dumiter, F., Brezeanu, P., Radu, C., Turcas, F. (2015)

Modelling Central Bank independence and inflation: Deus ex machina?

problems confronted by the central banks at the beginning of their functioning were bounded to the contradictory obligations.

The most important underlying problems regarding the central bank independence was revealed by Touffout $(2008$, p. 8$)$ : "in what is the independence granted by the sovereign - the government - a credible obstacle to any of that sovereign's subsequent actions? What is has granted, is it not within its power to take away again? Put another way, how can central bank independence be made truly credible?"

Laurens et al. (2009, p. 2) suggest that: "central bank independence has significant benefits in macroeconomic performance as it helps countries achieve lower average inflation, cushion the impact of political cycles on economic cycles, and boost fiscal discipline without any additional costs or sacrifices in terms of output volatility or reduced economic growth".

The policy of assuring a high degree of independence to the central banks has been actually since 1990's, where the vast majority of countries granted autonomy to their central banks. Cukierman (1994) highlights the main reasons behind the adoption of this institutional swift:

- The fixed exchange rates experience determined countries to designate institutions which are bounded to the price stability commitment.

- Independence is a condition for the adherence to the Euro Zone monetary block.

- The quod erat demonstrandum relationship between central bank independence and inflation revealed by the Deutsche Bundesbank.

According to Tshiani (2008, p. 4):'The primary goal of a central bank is to develop and maintain efficient monetary system whose primary goal is price and financial stability, but it remains an open question as to what an ideal central bank look like...The point to emphasize is that success on the inflation front is necessary if the central bank is to stabilize short-run fluctuations in real economic activity".

Other authors in analyzing the impact of central bank independence had come to the conclusion: "central bank independence has become one of the central concepts in monetary theory and policy. Most economists agree that central bank independence it helps to reach the long-term goal of price stability. Although one might think about alternative mechanisms to reach low inflation rates, central bank independence is one most-often recommended" (Siklos et al. 2010, p. 5).

It is very important to evaluate and assess inter countries comparison regarding central bank independence, starting from the born of these central banks until nowadays, the most developed central bank being: Bank of England, Banque de France, Deutsche Bundesbank, Federal Reserve.

Regarding the emerging countries form Central and Eastern Europe, their road to a market economy has been empowered with substantial institutional changes. The 
Dumiter, F., Brezeanu, P., Radu, C., Turcas, F. (2015)

Modelling Central Bank independence and inflation: Deus ex machina?

willingness and disposal regarding the adherence to the European Union has led to these countries, especially in Czech Republic and Hungary to engage in important institutional reforms. Other developing countries, especially those from South America: Argentina, Mexico and Columbia have increased the legal degree of central bank independence, as an integral parcel of the stabilization program.

A very important aspect regards the presentation of the social character of the money, and consequently of the ethical and moral powers of the central banks. It is important to reveal the main importance of the money, the institutional character of the entities they generate, or the quid pro quo role of the central banks is the issuance and distribution of the money in society. Highlighting the social character of the central banks is leading to a more comprehensive perception of the monetary policy strategies, strategies oriented towards a nominal anchor. In this sense central bank independence can be seen as an international monetary system constitutive rule because a nominal anchor is seen as a background of an international monetary stability and also as a global financial governance mechanism.

Specialists like Adolph (2013, p. 3) see the central bank as a bureaucratic organization and debates the delegation and institutions in political economy:" if models and measures of bureaucratic preference can shed new light even on monetary technocrats, there is little doubt the same techniques will reveal new insights about regulators and policy implementers in all corners of the state".

Another very insightful study regarding the important nature of central bank independence represents the studies of Carlo Tognato. Tognato (2012) highlights the symbolical performances of the cultural impact of central bank independence:" in the light of such challenges, understanding the link between legitimacy, public support and central bank independence may turn out to be a valuable asset. So far, scholars and practitioners have intuitively perceived that culture may have something to do with it and have even coined a concept - that of stability culture to refer to that link....Stability cultures, in other words, are simply described as cultures conducive to macroeconomic stability...Independent central banks, as a result, find it easier to keep inflation under check, because their societies more willingly accept the sacrifices that come along with a tight monetary policy" (Tognato, 2012, p. 3).

The final scope of this paper was stricto sensu, to establish the nature and type of the causal relationship between the complex synergy of central bank independence and inflation, throughout modeling these two variables in a conductive way. Modeling the complex relationship between central bank independence and inflation in order to explain the volatility of inflation due to an institutional factor as central bank independence is an important asset. Moreover, the lato sensu description of central bank independence as a set of variables and not only a metrical de jure and de facto independence indices represents an important tool for 
Dumiter, F., Brezeanu, P., Radu, C., Turcas, F. (2015)

Modelling Central Bank independence and inflation: Deus ex machina?

clarifying this complex relationship between central bank independence and inflation.

\section{Literature review}

The causal relationship between central bank independence and inflation has started from the idea that between central bank de jure independence and central bank de facto independence there is a gap which produces a lack of soundness. In the monetary policy and central bank literature this is the so-called legalistic illusion debated by Andre Orlean (2008). According to this feature, the legalistic illusion represents the hypothesis in which the legislative enactment of the commitments will offer a credible protection of the central bank's autonomy against the adverse government actions. This is because in the literature regarding central banking and monetary policy the legal enactments represent the main source of credibility. The rationality behind this reason is the high importance attached to the central banks charter in the last three decades.

We can also see the fact that the vast majority empirical indexes regarding the measurement of central bank independence are assessed throughout de jure indices, based on the central bank charter, these are the classical indexes of Cukierman (1992), Cukierman et al. (1992). However, in time the economic literature highlighted the importance of the de facto central bank indicators based on the real aspects and practices of the central banks. In this sense Cukierman (1992) and Cukierman and Webb (1995) recalibrate measures of real aspects of central banks. Ciccarone \& Marchetti (2012) reveal the fact that in cases in which uncertainty is reflected in central bank's degree of conservativeness, the incentive contracts do not eliminate the inflation bias which may be positive or negative. According to Aziz, "the independence of the ECB to carry out its' tasks should not be pictured as the failure of democracy system in the EU to impose any type of ex ante commitment over the parameters of monetary management (Aziz, 2005, pp.545).

Other authors like Campoy and Negrete (2008, pp.197) suggest that: "central bank independence is a well-known remedy to the inflation bias arising when a timeinconsistency problem of discretionary monetary policy is present...if principals cooperate, the inflation bias is eliminated when their output target is different but not when they disagree over the inflation objective".

In compliance with the studies of Campoy and Negrete, Bibow (2004) made some actual reflections regarding the central bank independence argument. The author had come to the conclusion that: "it is most serious dangerous that the inflation bias of the time inconsistency theme has fostered such a one-side and counter biased approach to central bank independence and monetary policy " (Bibow, 2004, pp.572). 
Dumiter, F., Brezeanu, P., Radu, C., Turcas, F. (2015)

Modelling Central Bank independence and inflation: Deus ex machina?

The main problems regarding the establishment of the causal relationship central bank independence and inflation was, in the first place the divergent final results of measuring with accuracy the level of central bank independence in developed, emerging and less developing countries. This is because in the past, it couldn't be identified a whole set of indicators generally valuable either for developed countries, emerging countries and less developed countries.

For the purpose to evaluate and assess the causal relationship between central bank independence and inflation we start from the following hypothesis:

- Central bank independence is inverse correlated with inflation and budgetary deficit.

- The public's view and attitude vis-á-vis of inflation is stronger in comparison with the public's attitude towards central bank independence.

- Central bank independence is correlated also with the unemployment rate, the financial system's degree of development, but not with economic growth.

- The correlation between central bank independence and inflation is an inverse one, because for attaining and maintaining price stability, the central bank must encompass its' actions to the political agency.

- In the developed countries there can be identified an inverse correlation between central bank independence (with higher grades of the central bank indices scores) which generate a low inflation rate.

- In the emerging and less developing countries the correlation between central bank independence and inflation cannot be sustained; this is because it can be identified a direct connection between the Turn - Over -Rate of central bank Governors and the Governing Board and inflation.

- The emerging countries which had registered high inflation rate in their transition and catching - up processes had granted a high level of central bank de jure independence because of the counter-inflationary signal enrich in the "minds" of the wide public.

- It is needed to the counted the so-called correlation between Turn - Over -Rate of central bank Governor and Board members and central bank independence in the context of a lower degree of conservativeness from the central bank; in this sense, there can be identified an inverse correlation between inflation and political and economical of a central bank.

- One of the best ways to impede the inflationary distress was the limitation for the central banks to the fulfillment of the price stability objective.

\section{The research methodology}

Regarding the modeling of the complex relationship between central bank independence and inflation we could identify two mainstream problems. In the first 
Dumiter, F., Brezeanu, P., Radu, C., Turcas, F. (2015)

Modelling Central Bank independence and inflation: Deus ex machina?

stage, most empirical studies regarding central banking and monetary policy couldn't provide a comprehensive approach regarding the multi-faced concept of central bank independence. In the second stage, in the vast majority of economic studies dealing with the relationship between central bank independence and inflation we can observe that either focuses on the developed country group, either on the developing one. In this sense it can be observed that there was a lack of measuring with accuracy central bank independence that could be applied, ceteris paribus, to the developed, emerging and less developing countries, taking into account some important facts as the quantity and quality of the economic data, time period and econometrical tools.

In this study we have defined central bank independence as a mixture of variables because of the multi-faced dimension of this monetary concept. The mainstream elements have at their grounds theoretical arguments $v i s-a ́ a-v i s$ of central bank independence and it's technical measure for assessing it's impact upon the inflation performances. In my opinion this fact is very important because focusing only on some de jure and de facto elements of central bank independence to explain the causality relation with inflation does not encompass all the real connections. In this sense we consider necessary the incorporation of both elements which are necessary for assessing the political nature of the economy and those who are bounded by the monetary theory.

In our study we have considered a linear model in which we will have inflation as the dependent variable, and the following independent variables: the economy degree of openness, exchange rate, GDP, interest rate, external debt. The relationship between central bank independence and inflation is revealed by introducing the following variables: central bank independence throughout the index for measuring central bank independence, transparency and accountability and political instability index.

The two important econometric methods used for attaining the paper's purposes are the Panel Data Model - Pooled Least Squares and Panel Model - Two Stage Least Squares. The time period was $2005-2014$, and the country group was divided into two subgroups: the first group was the developed country group engaging countries as: United States, New Zeeland, Japan, United Kingdom, Euro Zone; the emerging country subgroup has engaging countries as: Romania, Poland, Czech Republic, Hungary and Bulgaria. The econometric software package Eviews 5.0 was used in order to establish the causal relations between inflation and central bank independence both in developed and developing countries, where the mathematical relations were as following:

$I N F_{i t}=\alpha+\beta_{1} x E D O_{i t}+\beta_{2} x P P P_{i t}+\beta_{3} x G D P_{i t}+\beta_{4} x I N R_{i t}+\beta_{5} x E X D_{i t}+\beta_{6} x C B I_{i t}+\beta_{7} x I P I_{i t}+\varepsilon_{i t}$ 
Dumiter, F., Brezeanu, P., Radu, C., Turcas, F. (2015)

Modelling Central Bank independence and inflation: Deus ex machina?

For the developed country group Least Squares Method:

$I N F_{i t}=a+0.007 x E D O_{i t}-0.003 x P P P_{i t}+0.08 G D P_{i t}-0.02 x I N R_{i t}-0.002 x E X D_{i t}+15.37 x C B I_{i t^{-}}$ $-2.25 x I P I_{i t}+\varepsilon_{i t}$

For the emerging country group Least Squares Method:

$I N F_{i t}=\alpha-0.003 x E D O_{i t}+0.001 x P P P_{i t}-0.77 G D P_{i t}-0.59 x I N R_{i t}-0.004 x E X D_{i t}+1.566 x C B I_{i t}+$ $+1.168 x I P I_{i t}+\varepsilon_{i t}$

For the developed country group Two Stage Least Squares Method:

$I N F_{i t}=a+0.006 x E D O_{i t}-0.001 x P P P_{i t}+0.055 G D P_{i t}-0.01 x I N R_{i t}-0.004 x E X D_{i t}+15.62 x C B I_{i t^{-}}$ $-2.05 x I P I_{i t}+\varepsilon_{i t}$

For the emerging country group Two Stage Least Squares Method:

$I N F_{i t}=\alpha+3.89 x E D O_{i t}+0.0005 x P P P_{i t}-1.37 G D P_{i t}-0.79 x I N R_{i t}-0.005 x E X D_{i t}+3.02 x C B I_{i t}+$ $1.22 x I P I_{i t}+\varepsilon_{i t}$

Where:

$\alpha=$ free coefficient;

$\varepsilon_{i t}=$ regression error.

INF - inflation - end of period consumer prices - percentage points;

EDO - the economy degree of openness;

PPP - Implied Purchasing Power Parity conversion rate (National Currency per current international dollar);

GDP - Gross Debt Product - based on Purchasing Power Parity (PPP) share of world total (\%);

INR - monetary policy real interest rate;

EXD - general government gross debt - percentage of GDP;

CBI - central bank independence;

IPI - index of political vulnerability.

Inflation represents the dependent variable of the model. This is measured throughout HPCI - Harmonized Prices Consumer Index - annual modification percentage. This variable is very important because a price consumer index measures a modification of prices for a fixed basket of goods and services, in time period and region.

Central bank independence will be represented by the total score of the index for measuring central bank independence, transparency and accountability (Dumiter, 2013). The rationale behind using this index a metrical measure was the less significant statistical results realized in time by different authors regarding the gap 
Dumiter, F., Brezeanu, P., Radu, C., Turcas, F. (2015)

Modelling Central Bank independence and inflation: Deus ex machina?

between legal independence and actual independence of central bank, but also for the necessity of assessing a new index which include aspects of transparency throughout conferring information to the public, civil society and mass-media upon the objectives, operations and monetary policy actions, and consequently, aspects of central bank accountability by assessing in the model of accountability and responsibility vis - $a-v i s$ of Government, Parliament and wide public by the central bank.

Political Instability Index shows the threats level which Government is subject by the social protests. The index scores are gathered by subsuming the two subindicators: measuring economic disturbances and assessing the vulnerability over the turbulences. The final score of the index vary between zero - minimum level (lack of vulnerability) and ten maximum levels (high vulnerability). The final score of the index represents the aggregation of the two sub-indices. There are fifteen variables of the index, twelve for the first sub-indicator: inequality, state's history, corruption, ethnic fragmentation, institutional trustworthiness, minority status, political instability history, labor market instability trends, society evolution's level, countries neighbors, political regime type, connection between political regime and it's factionalism; all three for the second sub-indicator: increases registered in the income level, unemployment rate, GDP per capital level.

The economy degree of openness is a concept extensive debated in the economic literature. In this case, the problem is not the equilibrium between exports and imports, but the quantity of exports and imports realized by a country in relationship with its' GDP. In this case, we used the commerce rate of GDP = (Exports + Imports) / GDP.

The exchange rate in this study is expressed throughout Purchasing Power Parity $(P P P)$. A monetary policy regime's efficiency depends by an independent exchange rate course. The PPP theory uses the long term equilibrium of two currencies exchange rates for equalizing their purchasing power.

Gross Debt Product based on Purchasing Power Parity - per capita expressed in U.S. Dollars. In this study we have considered the expression of GDP based on PPP in U.S. dollars per capita. The data are constructed throughout dividing GDP in PPP at U.S. dollars reported to the total number of population.

Monetary policy interest rate. Monetary policy represents a process throughout Government, central bank or the monetary authority of a country controls the money supply, cash availability, money cots or interest rates, for the purpose of attaining a whole set of objectives oriented towards economic growth and economy stability.

External debt in this study is expressed as a percentage from GDP. External debt or foreign debt represents a part of the total debt of a country which is owned by the creditors from abroad. The debt includes the money owed to commercial banks, 
Dumiter, F., Brezeanu, P., Radu, C., Turcas, F. (2015)

Modelling Central Bank independence and inflation: Deus ex machina?

other governments or international financial institutions as International Monetary Fund or World Bank.

\section{Empirical results}

Tables 1 and 2 reveal the econometrical testing results of modeling central bank independence and inflation in the developed country group. As it can be seen, according to table 1 there is a significant relationship between central bank independence and inflation throughout the Least Squares Method. With a $\mathrm{R}^{2}=0.71$ there can be identified a very strong statistical correlation between these two variables. The Durbin Watson Test reveals that the residual variables are slightly left correlated. Within this model inflation is positive correlated with the economy degree of openness, GDP, and central bank independence, while with exchange rate, interest rate, external debt and political instability index there can be identified a negative correlation.

Table no. 1 Empirical results of modeling central bank independence and inflation in developed countries - Pooled Least Squares Method

Dependent Variable: INF?

Method: Pooled Least Squares

Date: 10/14/15 Time: 20:04

Sample: 20052014

Included observations: 10

Cross-sections included: 4

Total pool (balanced) observations: 40

Cross sections without valid observations dropped

\begin{tabular}{|c|r|r|r|r|}
\hline Variable & Coefficient & Std. Error & t-Statistic & \multicolumn{1}{|c|}{ Prob. } \\
\hline EDO? & 0.007553 & 0.006343 & 1.190750 & 0.2422 \\
\hline PPP? & -0.003092 & 0.019249 & -0.160618 & 0.8734 \\
\hline GDP? & 0.085404 & 0.196713 & 0.434153 & 0.6670 \\
\hline INR? & -0.022057 & 0.111605 & -0.197634 & 0.8445 \\
\hline EXD? & -0.002937 & 0.010789 & -0.272202 & 0.7872 \\
\hline CBI? & 15.37677 & 12.32506 & 1.247602 & 0.2210 \\
\hline IPI? & -2.254679 & 2.275570 & -0.990820 & 0.3290 \\
\hline R-squared & 0.710521 & Mean dependent var & 2.346125 \\
\hline Adjusted R-squared & 0.657888 & S.D. dependent var & 1.932025 \\
\hline S.E. of regression & 1.130048 & Akaike info criterion & 3.240025 \\
\hline Sum squared resid & 42.14124 & Schwarz criterion & 3.535578 \\
\hline Log likelihood & -57.80049 & F-statistic & 13.49964 \\
\hline Durbin-Watson stat & 1.366505 & Prob(F-statistic) & 0.000000 \\
\hline
\end{tabular}

Source: Own estimation 
Dumiter, F., Brezeanu, P., Radu, C., Turcas, F. (2015)

Modelling Central Bank independence and inflation: Deus ex machina?

The Two Stage Least Squares method in the developed country group is highlighted in table2. In this case, Tables 2 reveals similar results of econometrical testing regarding the complex relationship between central bank independence and inflation with a strong statistical correlation $\left(\mathrm{R}^{2}=0.70\right)$, a Durbin Watson statistical test with little left autocorrelation of the residual variables and a positive correlation between inflation and the economy degree of openness, GDP and central bank independence.

Table no. 2 Empirical results of modeling central bank independence and inflation in developed countries - Two-stage Least Squares

Dependent Variable: INF?

Method: Pooled IV/Two-stage Least Squares

Date: 10/14/15 Time: 19:11

Sample (adjusted): 20052014

Included observations: 9 after adjustments

Cross-sections included: 4

Total pool (balanced) observations: 36

Instrument list: c @ cxinst edo?(-1)ppp?(-1)gdp?(-1)inr?(-1)exd?(-1)cbi?(-1)ipi?(-1)

Cross sections without valid observations dropped

\begin{tabular}{|c|r|r|r|r|}
\hline Variable & Coefficient & Std. Error & t-Statistic & Prob. \\
\hline EDO? & 0.006598 & 0.006745 & 0.978208 & 0.3361 \\
\hline PPP? & -0.001194 & 0.022559 & -0.052922 & 0.9582 \\
\hline GDP? & 0.055769 & 0.226644 & 0.246065 & 0.8074 \\
\hline INR? & -0.010971 & 0.127536 & -0.086019 & 0.9320 \\
\hline EXD? & -0.004825 & 0.012157 & -0.396898 & 0.6943 \\
\hline CBI? & 14.62410 & 13.51977 & 1.081683 & 0.2883 \\
\hline IPI? & -2.050685 & 2.497814 & -0.820992 & 0.4183 \\
\hline R-squared & 0.707466 & Mean dependent var & 2.370139 \\
\hline Adjusted R-squared & 0.646942 & S.D. dependent var & 1.883656 \\
\hline S.E. of regression & 1.119245 & Sum squared resid & 36.32854 \\
\hline Durbin-Watson stat & 1.497403 & Instrument rank & 24.00000 \\
\hline
\end{tabular}

Source: Own estimation

Table 3 and 4 reveal the results of the econometrical tests of modeling central bank independence and inflation in the emerging country group. As it can be seen in table 3 there can be identified a statistical relevant correlation between central bank independence and inflation with a $\mathrm{R}^{2}=0.58$ and a Durbin Watson statistical test within a slight right correlation of the residual variables. However, there can be identified a positive correlation between inflation and the economy degree of openness, exchange rate, central bank independence and political instability index, while between GDP, interest rate and external debt it can be seen a negative correlation. 
Dumiter, F., Brezeanu, P., Radu, C., Turcas, F. (2015)

Modelling Central Bank independence and inflation: Deus ex machina?

\section{Table no. 3 Empirical results of modeling central bank independence and inflation in emerging countries - Pooled Least Squares Method}

\begin{tabular}{|c|c|c|c|c|}
\hline \multicolumn{5}{|c|}{$\begin{array}{l}\text { Dependent Variable: INF? } \\
\text { Method: Pooled Least Squares } \\
\text { Date: } 10 / 15 / 15 \text { Time: } 11: 59 \\
\text { Sample: } 20052014 \\
\text { Included observations: } 10 \\
\text { Cross-sections included: } 4 \\
\text { Total pool (balanced) observations: } 40 \\
\text { Cross sections without valid observations dropped }\end{array}$} \\
\hline Variable & Coefficient & Std. Error & t-Statistic & Prob. \\
\hline EDO? & 0.003366 & 0.003857 & 0.872890 & 0.3890 \\
\hline PPP? & 0.001852 & 0.012009 & 0.154198 & 0.8784 \\
\hline GDP? & -0.770890 & 1.711822 & -0.450333 & 0.6554 \\
\hline INR? & -0.592916 & 0.148096 & -4.003595 & 0.0003 \\
\hline EXD? & -0.004793 & 0.034498 & -0.138941 & 0.8903 \\
\hline CBI? & 1.566961 & 1.938152 & 0.808482 & 0.4246 \\
\hline IPI? & 1.168654 & 0.198760 & 5.879731 & 0.0000 \\
\hline R-squared & 0.582607 & \multicolumn{2}{|c|}{ Mean dependent var } & 3.948050 \\
\hline Adjusted R-squared & 0.506717 & \multicolumn{2}{|c|}{ S.D. dependent var } & 2.209880 \\
\hline S.E. of regression & 1.552089 & \multicolumn{2}{|c|}{ Akaike info criterion } & 3.874709 \\
\hline Sum squared resid & 79.49637 & \multicolumn{2}{|c|}{ Schwarz criterion } & 4.170263 \\
\hline Log likelihood & -70.49418 & \multicolumn{2}{|c|}{ F-statistic } & 7.677030 \\
\hline Durbin-Watson stat & 2.659608 & \multicolumn{2}{|c|}{ Prob(F-statistic) } & 0.000033 \\
\hline
\end{tabular}

Source: Own estimation

Table 4 highlights the results of the econometrical testing according to the Two Stage Least Squares Method in the emerging country group. As it can be seen the $\mathrm{R}^{2}=0.54$ reveal a statistical significant relationship between central bank independence and inflation, and a Durbin Watson statistical test of 2.71 which suggest a slight right autocorrelation of the residual variables. However, in the emerging country group there can be identified a positive correlation between inflation and the economy degree of openness, exchange rate, central bank independence and political vulnerability index, while between inflation and GDP, interest rate and external debt we can identify a negative correlation.

\section{Conclusions}

The empirical study highlights the importance of the central bank institution and it's fundamental role in any economy or society, the crucial role of the central bank's decision-makers enriched in the monetary policy delegation process, the degree of interference of the political partisans in the monetary policy process, the 
Dumiter, F., Brezeanu, P., Radu, C., Turcas, F. (2015)

Modelling Central Bank independence and inflation: Deus ex machina?

tradeoff between central bank independence and central bank accountability, and also the complex relationship between central bank independence and inflation.

Table no. 4 Empirical results of modeling central bank independence and inflation in emerging countries - Two-stage Least Squares

Dependent Variable: INF?

Method: Pooled IV/Two-stage Least Squares

Date: 10/15/15 Time: 12:01

Sample (adjusted): 20052014

Included observations: 9 after adjustments

Cross-sections included: 4

Total pool (balanced) observations: 36

Instrument list: c@cxinst edo?(-1) ppp?(-1)gdp?(-1)inr?(-1)exd?(-1)cbi?(-1)ipi?(-1) Cross sections without valid observations dropped

\begin{tabular}{|c|r|r|r|r|}
\hline Variable & Coefficient & Std. Error & t-Statistic & \multicolumn{1}{c|}{ Prob. } \\
\hline EDO? & $3.89 E-05$ & 0.005722 & 0.006801 & 0.9946 \\
\hline PPP? & 0.000545 & 0.014756 & 0.036959 & 0.9708 \\
\hline GDP? & -1.377833 & 2.002203 & -0.688159 & 0.4968 \\
\hline INR? & -0.765336 & 0.198406 & -3.857427 & 0.0006 \\
\hline EXD? & -0.005110 & 0.042688 & -0.119716 & 0.9055 \\
\hline CBI? & 3.028280 & 2.312873 & 1.309315 & 0.2007 \\
\hline IPI? & 1.228313 & 0.233403 & 5.262636 & 0.0000 \\
\hline R-squared & 0.541178 & Mean dependent var & 3.995028 \\
\hline Adjusted R-squared & 0.446249 & S.D. dependent var & 2.210391 \\
\hline S.E. of regression & 1.644850 & Sum squared resid & 78.46039 \\
\hline Durbin-Watson stat & 2.717339 & Instrument rank & 24.00000 \\
\hline
\end{tabular}

Source: Own estimation

The study highlights the important institutional shifts oriented towards increasing the degree of central bank independence in compliance with a high degree of central bank accountability and central bank transparency, in order to assess and strengthened central bank credibility. Regarding these aspects we could survey that the central banks from the developed country groups like: Federal Reserve, European Central Bank, Reserve Bank of New Zeeland, Bank of England and less Bank of Japan hold very powerful central banks with a high degree of central bank independence and independent monetary policy regimes.

The central banks within the emerging country group: National Bank of Romania, National Bank of Czech Republic, National Bank of Hungary, National Bank of Poland and National Bank of Bulgaria continue the so-called „road" to a more de facto independent central bank, an increasing degree of central bank transparency and openness and a more comprehensive accountability vis $-a ́ a-v i s$ of the most democratic institutions, especially the Parliament. 
Dumiter, F., Brezeanu, P., Radu, C., Turcas, F. (2015)

Modelling Central Bank independence and inflation: Deus ex machina?

The two types of techniques presented in this paper highlights that the correlation between central bank independence and inflation both in developed and developing countries are "sensible" to a wide range of control variables, due to the multi-faced nature of central bank independence and to the spurious trend of inflation. However modeling central bank independence and inflation has shown that central bank independence accompanied with several macroeconomic indicators can explain the fluctuation in the inflation level, the models show, in the end, than central bank independence throughout the political instability and the impact of political circle upon the central bank can be a factor of increasing the level on inflation and enduring the inflation culture.

In our opinion, the cultural factor represents a very important one. The limitation of this study is given the lack of the cultural features which can have a main impact upon macroeconomic stability. Moreover, the in future research we want to tackle the influence of some cultural and educational trends upon the inflation which have a strong impact upon the macroeconomic stability. Consequently, in future studies it is important to tackle the policy mix between monetary and fiscal policy in the macroeconomic policy mix. In this sense it is important to analyze and study the impact of the Hofstede model upon the internal quality of the central bank and upon the inflation performances.

\section{References}

1. Adolph, C., 2013. Bankers, Bureaucrats, and Central Bank Politics: The Myth of Neutrality (Cambridge Studies in Comparative Politics), Cambridge University Press.

2. Aziz, N., 2005, Power Delegation of European Central Bank's democratic deficit, American Economic Journal 3, pp. 537-550.

3. Bibow, J., 2004, Reflections on the current fashion for central bank independence, Cambridge Journal of Economics 28, pp. 549 - 576.

4. Campoy, J, Negrete, J., 2008, Optimal central banker contracts and common agency: a comment, Public Choice 137, pp. 197-206.

5. Ciccarone, G., Marchetti, E., 2012, Optimal linear contracts under common agency and uncertain central bank preferences, Public Choice 150, pp. 263-282.

6. Cukierman, A., 1992. Central bank strategy, credibility and independence Theory and Evidence, MIT Press.

7. Cukierman, A., Webb, S.B., Neyapti, B., 1992. Measuring the Independence of central banks and its effects on policy outcomes, The World Bank Economic Review 6.

8. Cukierman, A., Webb, S.B., 1995. Political influence on the central bank: International evidence, The World Bank Economic Review 9. 
Dumiter, F., Brezeanu, P., Radu, C., Turcas, F. (2015)

Modelling Central Bank independence and inflation: Deus ex machina?

9. De Haan, J., Masciandaro, D., Quintyn, M., 2008. Does central bank independence still matter? European Journal of Political Economy, 24, 717-721.

10. Dumiter, F., 2013. Banca centrala ca ramura a birocratiei, in vol. II, Studii si Cercetari Financiar - Monetare, Studii post-doctotale in economie, Disertatii Post-Doctorale, Editori Acad. Ioan Paun Otiman, Prof. univ. dr. Cornel Ionescu, Prof. univ, dr. Emil Dinga, Ed. Academiei Romane, pp. 500 - 560.

11. Eijffinger, S.C.W., Geraats, P., 2006. How transparent are central banks? European Journal of Political Economy, Vol. 22, pp. 1-21.

12. Hughes Hallet, A., Libich, J., 2011. Explicit inflation target and central bank independence: friends or foes? Econ Change Restruct, Springer, pp.1-27.

13. Iversen, T., 1999. The political economy of inflation: Bargaining structure or central bank independence? Public Choice, 99, 237-258.

14. Klomp, J., de Haan, J., 2010. Central bank independence and inflation revised, Public Choice, 144, 445-457.

15. Laurens, B.J., Arnone, M., Segalotto, J-F, 2009. Central Bank Independence, Accountability and Transparency - A Global Perspective, International Monetary Fund, Palgrave MacMillan.

16. Masciandaro, D., Quintyn, M., Taylor, M., 2008. Inside and outside central bank: Independence and accountability in financial supervision, Trends and determinants, European Journal of Political Economy, 24, 833-848

17. Miles, W., Vijverberg, C.P., 2011. Formal targets, central bank independence and inflation dynamics in the UK: A Markow-Switching approach, Journal of Macroeconomics, 33, pp. 644-655.

18. Ollala, M.G., Gomez, A.R., 2011. Robust Control and central bank behavior, Economic Modelling, 28, pp. 1265-1278.

19. Siklos, P., 2008. No single definition of central bank independence is right for all countries, European Journal of Political Economy 24, pp. 802-816.

20. Siklos, P., Bohl, M., Wohar, M., 2010. Challenges in Central Banking - The Current Institutional Environment and Forces Affecting Monetary Policy, Cambridge University Press.

21. Thisani, N.K., 2008. Building Credible Central Banks: Policy Lessons for Emerging Economies, Palgrave MacMillan Studies in Banking and Financial Institutions.

22. Tognato, C., 2012, Central Bank Independence: Cultural Codes and Symbolic Performances (Cultural Sociology), Palgrave MacMillan.

23. Touffut, J-P, 2008. Central Banks as Economic Institutions, The Cournot Centre for Economic Studies Series, Edward Elgar.

24. Vaderhart, P.G., 2009. What is the best way to impede a central bank? The Quarterly Review of Economics and Finance, 49, pp. 784-779. 